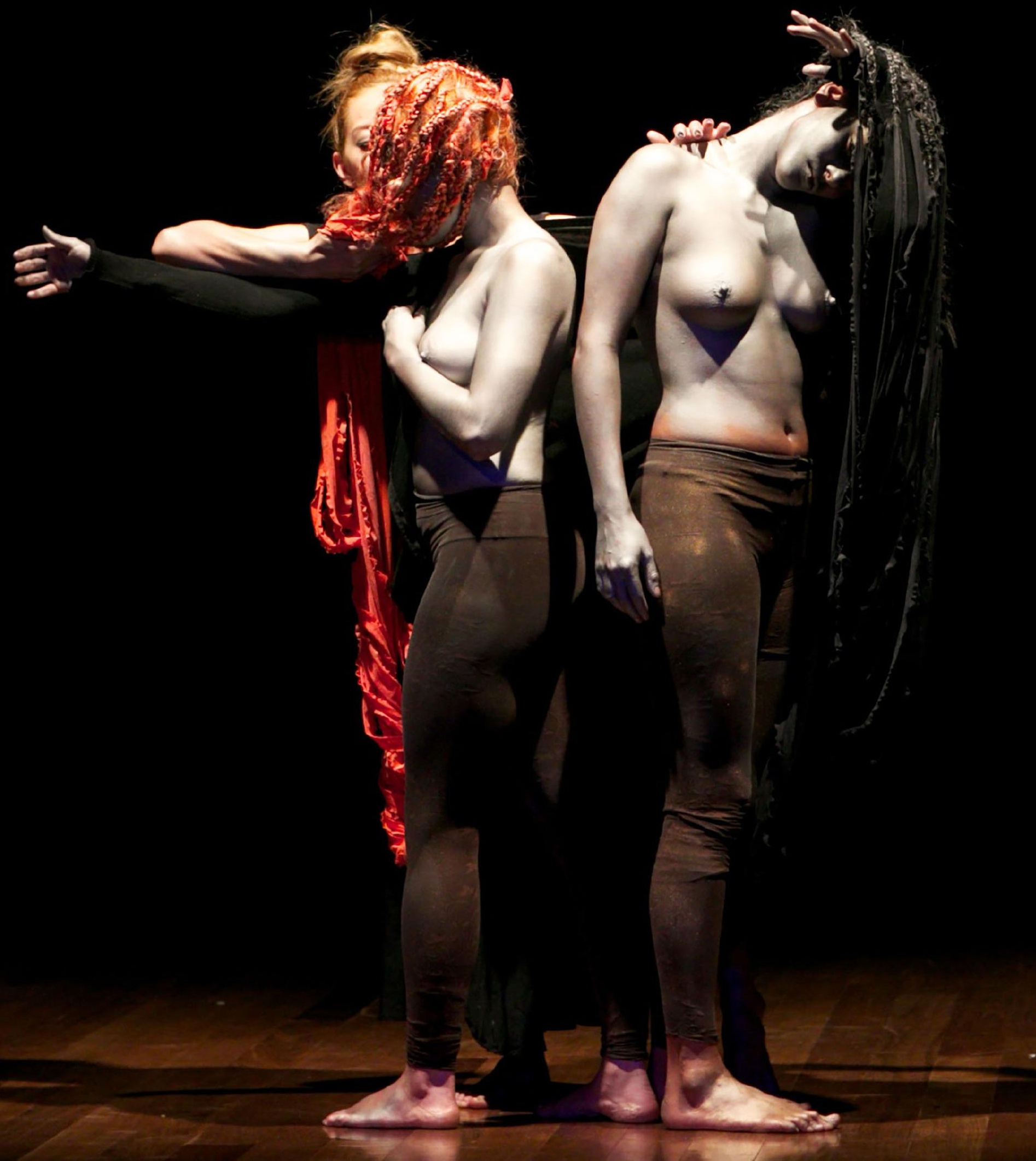




\section{Joven, reconocida, pero frágil}

\author{
Pedro Pablo Gómez Moreno \\ Editor \\ Universidad Distrital Francisco José de Caldas, \\ Colombia \\ ppgomezm@udistrital.edu.co \\ Cómo citar este artículo: Gómez Moreno, \\ Pedro Pablo (2020). Joven, reconocida pero \\ frágil. Estudios Artísticos: revista de investiga- \\ ción creadora 6(8) pp. 14-16 DOI https://doi. \\ org/10.14483/25009311.15688
}

La Factoría (2012). Danza IV año, énfasis interpretación.

Fotografía: Carlos Mario Lema.

\section{(c) (i)}

https://creativecommons.org/licenses/by/4.0/deed.es
Estudios Artísticos: revista de investigación creadora, es una de las revistas académicas más jóvenes del campo del arte en Colombia y en América Latina. Creada en 2015, como iniciativa de un grupo de artistas que a la sazón nos encontrábamos en la tarea de posicionar un campo emergente para la formación y la investigación creación denominado precisamente estudios artísticos, porque vimos la necesidad de contar con un medio adecuado para la socialización de los resultados de investigación y creación de los estudios artísticos.

Al comienzo fue una publicación de periodicidad anual, porque intentábamos superar la fase crítica de toda publicación; se dice en Colombia que la mayoría de las nuevas publicaciones seriadas desaparecen antes de su tercera edición. $Y$ esto tiene sentido, pues como bien es sabido, la sostenibilidad de una publicación académica depende, por una parte, de la financiación institucional y de otra, que es la más importante, de la confianza que depositan en ella los autores, quienes envían sus trabajos académicos para su evaluación y posterior publicación. Si los autores no confían en la política editorial de una revista, en la calidad y rigor de sus procesos, así como en el equipo editorial que la agencia, no es viable la sostenibilidad de una publicación por ausencia de contenidos. De ahí que los investigadores y creadores sean los protagonistas de nuestra revista, la cual es nada más que un medio de circulación que propicia la apropiación social del conocimiento.

En concordancia con lo anterior, en Estudios Artísticos, somos cautos en sugerir temáticas para nuestra revista. Consideramos que los temas corresponden a los intereses de las comunidades investigativas quienes eligen y configuran los problemas de investigación y creación que consideran pertinentes para el desarrollo de su 
propio campo de conocimiento $y$, a su vez, para dar respuesta a cuestiones concretas de la vida práctica. Como medio de socialización, Estudios Artísticos recoge una diversidad de resultados que dan cuenta de los debates contemporáneos de las artes en diálogo con las ciencias sociales y las ciencias humanas.

Entre las secciones de la revista vale la pena destacar la sección: Pensamiento sensible, en la que damos cabida a propuestas relevantes de artistas y creadores que sean consistentes con el enfoque de Estudios Artísticos. En esta sección publicamos artículos de investigación creación, en los que las imágenes tienen igual o mayor protagonismo que el texto, puesto que las imágenes son soporte del pensamiento al igual que la escritura alfabética. Por lo tanto, un ensayo visual tiene la misma validez que un ensayo escrito, y en él el protagonismo perfectamente puede estar en la textualidad de la imagen, cuyos códigos y símbolos son abiertos y semántica y sintácticamente más densos que los códigos de la escritura científica.

A la fecha, hemos publicado más de 60 artículos que dan cuenta de lo dicho, con una variedad de temas y una variedad de autores que cuentan con reconocimiento mundial al lado de autores jóvenes con una gran proyección académica. También, hemos logrado indexar la revista en el Directory of Open Access Journals (DOAJ); en La Red Iberoamericana de Innovación y Conocimiento
Científico (REDIB) y en Actualidad Iberoamericana. Para 2018, nos dimos cuenta que cumplíamos con todos los requisitos para participar en la convocatoria de Publindex Colombia, con el fin de formar parte del Índice Bibliográfico Nacional. Obtuvimos el aval institucional y avanzamos en todas las etapas del proceso de evaluación; en los resultados finales Estudios Artísticos: revista de investigación creadora, fue reconocida como revista científica y sin embargo no fue clasificada, debido a que, por ser una revista joven, su índice $\mathrm{H}$ (que mide el número de citaciones que se realiza a un artículo en un periodo de tiempo determinado) es aún bajo con respecto a todas las revistas del área de humanidades con las que se le compara en el proceso de evaluación.

Lo anterior, contrario a desanimarnos, nos motiva para seguir adelante en el propósito de posicionar cada vez más nuestra revista entre las mejores publicaciones académicas fronterizas en y desde Colombia, por su carácter abierto, plural, como corresponde a una publicación que surge en una institución pública, cuya misión tiene que ver con la democratización del acceso a la formación y al conocimiento. Aunque joven, Estudios Artísticos no entiende la juventud como ausencia de historia y experiencia, sino como la potencia necesaria para marcar puntos de bifurcación en la historia y la posibilidad de narrarla de otros modos, con otros protagonistas y por qué no, como la posibilidad de cambiarla. 